\title{
Cardiovascular risk factors and white matter hyperintensities in patients with migraine without aura
}

\author{
Aurasız migrenli hastalarda kardiyovasküler risk faktörleri ve beyaz cevher hiperintensiteleri \\ Ceyla Ataç UÇAR, Hafize Nalan GÜNEŞ, Cemile SENCER DEMIRCAN, Burcu Gökçe ÇOKAL, Selda KESKiN GÜLER, \\ Tahir Kurtuluş YOLDAŞ
}

\begin{abstract}
Summary
Objectives: White matter hyperintensities (WMHs) are observed in patients with migraine with aura (MWA) and without aura (MWO), but there are a limited number of studies regarding patients with MWA. In this study, we aimed to investigate the cardiovascular risk factors which may play a role in the development of WMHs in patients with MWO.

Methods: This observational, analytical, case-control study was conducted between June 2016 and January 2017. It included 21 patients with MWO who had WMHs on brain MRI and 19 patients with MWO who tested normal on MRI (control group) at the Neurology Department Outpatient Polyclinic, Ankara Training and Research Hospital. The patients' data (history, family history, neurological examination findings, echocardiography findings, and cerebral MRI findings) were retrospectively reviewed.

Results: Age, gender, body mass index, blood lipid level, migraine duration, localization of headache, average number of headache per month, medication for headache attack, and echocardiography findings were similar between the two groups. ( $p>0.05$ ).

Conclusion: In this study, we did not find any association between cardiovascular risk factors and WMHs development in patients with MWO. The association of risk factors other than cardiovascular risk factors (genetic factors and oxidative stress) with the development of WMHs in patients with MWO should also be studied in future.
\end{abstract}

Keywords: Cerebral white matter hyperintensities; migraine without aura; risk factors.

\begin{abstract}
Özet
Amaç: Beyaz cevher hiperintensiteleri (BCH) hem auralı migrenli (MWA), hem de aurasız migrenli (MWO) li hastalarda görülmekle birlikte, MWA'ı hastalarda sınırlı sayıda çalışma yapılmıştır. Biz bu çalışmada MWA'ı hastalarda BCH'lerinin gelişiminde rol oynayan kardiyovasküler risk faktörlerini araştırmayı amaçladık.

Gereç ve Yöntem: Bu gözlemsel, analitik, vaka-kontrol çalışması Temmuz 2016-Ocak 2017 tarihleri arasında Ankara Eğitim ve Araştırma Hastanesi Nöroloji Polikliniği'ne başvuran, MWO tanısı almış ve serebral MRG 'da BCH saptanan 21 olgu ve kontrol grubu olarak serebral MRG'da BCH saptanmayan 19 MWO olgusu ile yapılmıştır. Hastaların yaş, cinsiyet, beden kitle indeksleri, kan lipid düzeyleri, migren hastalık süresi, başağrısının lokalizasyonu, aylık ortalama başağrısı sayısı, atakta kullanılan ilaçlar ve ekokardiyografi bulguları retrospektif olarak gözden geçirildi.

Bulgular: Hastaların yaş, cinsiyet, beden kitle indeksleri, total kolesterol (kol), migren hastalık süresi, başağrısının lokalizasyonu, aylık ortalama başağrısı sayısı, atakta kullanılan ilaçlar ve ekokardiyografi bulguları benzerdi. ( $p>0.05)$

Sonuç: Çalışmamızda kardiyovasküler risk faktörleri ile MWO hastalarında BCH gelişimi arasında ilişki bulmadık. Kardiyovasküler risk faktörleri dışındaki risk faktörleri ( genetik faktörler ve oksidatif stress vb) nin MWO'ı olgularda BCH gelişimindeki rolleri araştırılmalıdır.
\end{abstract}

Anahtar sözcükler: Aurasız migren; risk faktörleri; serebral beyaz cevher hiperintensiteleri.

\section{Introduction}

Migraine is a primary headache, with a prevalence of $11 \%$ worldwide. ${ }^{[14]}$ The findings on neurological examination and brain imaging are expected to be normal as in other primary headache syndromes; therefore, magnetic resonance imaging (MRI) of the cerebral cortex is performed to exclude secondary causes. But since the 1990's, detection of cerebral white matter hyperintensities (WMHs) have been reported on the MRI of patients with migraine. A study reported that $19 \%$ of the 38 patients with migraine had focal hyperintense lesions on cerebral MRI. ${ }^{[5]} \mathrm{An}$ - 
other population-based study reported infratentorial lesions in $4.4 \%$ of the 295 patients with migraine..$^{[7]}$ WMHs can be seen in patients with migraine, both with and without aura (MWA and MWO, respectively), but a limited number of studies have been conducted including patients with MWO. ${ }^{[15]}$

Different hypotheses have been proposed regarding the mechanisms underlying WMHs in patients with migraine, such as prolonged and repeated oligemia during migraine attacks affecting vulnerable, small, deeply penetrating arteries; vascular risk factors; endothelial dysfunction; genetic risk factors; use of antimigraine agents with vasoconstrictor effects; and cardiac abnormalities, including patent foramen ovale (PFO). ${ }^{[3]}$ When the etiology of WMHs in the general population are reviewed, it is observed that WMHs reflect chronic small vessel ischemia. Cardiovascular risk factors, including hypertension, hyperlipidemia, diabetes mellitus, smoking, history of coronary artery disease, cerebrovascular disease, and dementia, and advanced age have been associated with an increased prevalence of WMHs. ${ }^{[9]}$ Therefore, it is speculated that cardiovascular risk factors may also play an important role in the development of WMHs in patients with migraine.

There are limited numbers of studies regarding the association between WMHs in patients with migraine and cardiovascular risk factors. ${ }^{[10,16]}$ Some studies have suggested that WMHs are subclinical marker for cardiovascular risk. ${ }^{[15]}$

We aimed to investigate cardiovascular risk factors which may play a role in the development of WMHs in patients with MWO. We compared patients with MWO with and without WMHs to determine the difference in cardiovascular risk between the two groups.

\section{Materials and Methods}

This study was conducted between June 2016 and January 2017 and included 21 patients with MWO who showed WMHs on brain MRI and 19 patients with MWO who showed normal findings on MRI (control group) at the Neurology Department Outpatient Polyclinic, Ankara Training and Research Hospital.

The study was approved by Ankara Training and Research Hospital Ethics Committee.
Patient data, including history, family history, neurological examination findings, and laboratory findings were retrospectively reviewed. Patient characteristics, such as age, gender, migraine type, migraine duration, migraine headache duration, average number of headaches per month, localization of headache, smoking, previous use of oral contraceptive pills, were recorded. MWO was diagnosed according to the International Headache Society-III beta (IHS-III $\beta$ ) criteria. ${ }^{[6]}$ Patients who had hypertension; diabetes mellitus; thyroid gland dysfunction; oncological, hematological, infectious, inherited, or neurological diseases other than migraine; or smoking or oral contraception history were excluded from the study.

The levels of total cholesterol (col), triglycerides (tg), high-density lipoprotein (hdl), low-density lipoprotein (Idl), vitamin B12, homocysteine, folic acid, thyroid stimulating hormone, thyroxine, triiodothyronine, and vasculitis markers [antinuclear antibody (ANA), antidsDNA, antiphospholipid IgM and IgG antibodies, antineutrophil cytoplasmic autoantibody] were noted.

The body mass index (BMI) was calculated by dividing the patient's weight $(\mathrm{kg})$ with height $\times$ height (m2) (acceptable BMI: preobesity, $\geq 25$ and $<30 \mathrm{~kg} /$ $\mathrm{m} 2$; obesity, $\left.\geq 30 \mathrm{~kg} / \mathrm{m}^{2}\right){ }^{[12]}$

The reports of echocardiography (eco) and cerebral MRI were collected from patients' medical files. Eco was recorded using Vivid 3 (General Electric Medical Systems, Norway) machine with a $2.5-\mathrm{MHz}$ probe.

Cerebral MRI was performed using Siemens Aera (1.5 Tesla; Aksial FSE T2, Aksiyal FLAIR, Aksial SE T1, Coronal FSE T2, T1 axial and sagittal DFOV: $20.1 \times 23.0$, tnk: $5.5 \mathrm{~mm}$, TE: $8.90 \mathrm{~ms}$, TR: $400.000 \mathrm{~ms}$, T2 DFOV: 18.7×23.0, THK:5.5 mm, TE: $105.00 \mathrm{~ms}$, TR: 3800.00 ms, Diff DFOV: $18.7 \times 23.0$, TE: 89.00 ms, TR: 6000.00 ms, THK: $4.0 \mathrm{~mm}$ )

WMHs were defined as the presence of hyperintense lesions on T2-weighted MRI and FLAilR which are not hypointense on T1-weighted MRI and are $>3 \mathrm{~mm}$ in size. ${ }^{[1]}$

\section{Statistical analysis}

The data was analyzed using the Statistical Package 
for Social Sciences (SPSS) for Windows 22.0 (SPSS Inc., Chicago, IL). The Pearson's chi-square and Fisher's exact tests were used to analyze cathegorical variables. The Student t-test was used to calculate statistical significance with normal distribution between two independent groups. The Mann-Whiteney U-test was used for evaluating statistical significance of non-normally distribuated data. The relationship between variables was analyzed using the Spearman correlation analysis. The statistical significance was accepted as $p<0.05$.

\section{Results}

In total, 40 patients with MWO were investigated in the study. The average age was $36.23 \pm 9.40$ (19-51) years; $95.5 \%(n=37)$ were females, and $7.5 \%(n=3)$ were males. Of the 40 patients, 21 (52.5\%) had WMHs on MRI and were included in the "patient" group, whereas 19 (47.5\%) did not have WMHs on MRI and were included in the "control" group. The demographic and clinical features of the groups are summarized in Table 1.

Age; gender; BMl; cholesterol, hdl, tg, Idl and levels;

Table 1. Clinical and demographic features of the patient and control groups

\begin{tabular}{|c|c|c|c|}
\hline & Patient group $(n=21)$ & Control group $(n=19)$ & $\mathbf{p}$ \\
\hline Age (years) & $41(23-49)$ & $39(19-51)$ & 0.452 \\
\hline \multicolumn{4}{|l|}{ Sex } \\
\hline Male & $2(9.5)$ & $1(5.3)$ & \multirow[t]{2}{*}{1.000} \\
\hline Female & $19(90.5)$ & $18(94.7)$ & \\
\hline $\mathrm{BMI}\left(\mathrm{kg} / \mathrm{m}^{2}\right)$ & $26.95(19.30-39.24)$ & $24.20(17.90-31.20)$ & 0.205 \\
\hline Total cholesterol & $188(95-255)$ & $188(112-258)$ & 0.957 \\
\hline $\mathrm{HDL}$ & $50(35-96)$ & $50(35-55)$ & 0.611 \\
\hline LDL & $105(69-165)$ & $110(51-176)$ & 0.768 \\
\hline Triglycerides & $111(41-346)$ & $120(57-195)$ & 0.830 \\
\hline Migraine duration (years) & $8(1-25)$ & $4(1-30)$ & 0.307 \\
\hline \multicolumn{4}{|l|}{ Associated symptoms } \\
\hline Nausea & $20(95.2)$ & $19(100)$ & $1.000^{\mathrm{a}}$ \\
\hline Photophobia & $18(85.7)$ & $18(94.7)$ & $0.607^{\mathrm{a}}$ \\
\hline Phonophobia & $13(61.9)$ & $7(26.8)$ & 0.113 \\
\hline Headache duration (hours) & $12(4-72)$ & $24(2-72)$ & 0.810 \\
\hline \multicolumn{4}{|l|}{ Headache localization } \\
\hline Bilateral & $13(61.9)$ & $7(36.8)$ & 0.113 \\
\hline Left & $5(23.8)$ & $9(47.4)$ & 0.119 \\
\hline Right & $9(42.9)$ & $10(52.6)$ & 0.536 \\
\hline Average number of attacks per month & $5(0.5-30)$ & $4(1-15)$ & 0.117 \\
\hline \multicolumn{4}{|l|}{ Medication for attack } \\
\hline Tryptans & $4(19.0)$ & $3(15.8)$ & \multirow[t]{2}{*}{$1.000^{\mathrm{a}}$} \\
\hline NSAll & $17(81.0)$ & $16(84.2)$ & \\
\hline \multicolumn{4}{|l|}{ Echocardiography findings } \\
\hline Pathology not found & $19(90.5)$ & $16(84.2)$ & \multirow[t]{2}{*}{$0.654^{a}$} \\
\hline Pathology found & $2(9.5)$ & $3(15.8)$ & \\
\hline \multicolumn{4}{|l|}{ Pathologies detected on echocardiography } \\
\hline ASD & $1(4.8)$ & 0 & \multirow{3}{*}{0} \\
\hline IAS & & $1(4.8)$ & \\
\hline Minimal MY & 0 & $3(15.8)$ & \\
\hline
\end{tabular}


Table 2. MRI findings of the patient group

\begin{tabular}{lc}
\hline Number of WMHs & \\
$5-10$ & $17(81.0)$ \\
$1-4$ & $4(19.0)$ \\
WMH localisation & \\
Periventricular & $18(85.7)$ \\
Parietal & $3(14.3)$ \\
Frontal & $3(14.3)$ \\
\hline
\end{tabular}

\#There were more than one localization, percentages were calculated by patient number.

migraine duration; localization of headache; average number of headaches per month; medications for headache attack; and eco findings were similar between the two groups ( $p>0.05$ ) (Table 1).

In the patient group, $81.0 \%(n=17)$ of patients had 5-10 WMHs on MRI, and 19\% had 1-4 WMHs. The location of WMHs were periventricular in $85.7 \%(n=15)$ of patients, parietal in $14.3 \%(n=3)$, and frontal in $14.3 \%(n=3)$. The MRI findings of the patient group are summarized in Table 2.

\section{Discussion}

In this study, we aimed to investigate the cardiovascular risk factors associated with the development of WMHs.

We did not find any statistically significant difference between the patient and control groups regarding blood lipid profile, BMI, and eco findings. Thus, we concluded that these risk factors were not associated with the development of WMHs.

Prolonged and repeated oligoemia during migraine attacks may affect the vulnerable, small, deeply penetrating arteries, and local critical hypoperfusion may lead to minor brain injury (white matter lesions). This mechanism explains the occurrence of WMHs in patients with MWO, but it is not clearly defined in case of MWO. ${ }^{[3]}$

Other risk factors (genetic predisposition and/or oxidative stress) which may lighten the mechanism of WMHs occurrence may need to be investigated.

The association between cardiovascular risk factors and migraine has been previously studied. The re- sults of our study are consistent with those of two previous studies that included a large sample size. In one prospective cohort study, 23840 patients with migraine without angina or cerebrovascular disease and who were aged $\geq 45$ years were followed up for 10 years; MWO was not associated with an increased risk of cerebrovascular diseases. In another population-based cohort study including 18725 males and females, the occurrence of death due to cardiovascular disease, coronary artery disease, and stroke was higher in patents with MWO than in non-headache controls, but no statistically significant difference was detected when patients with MWO and nonmigraine headache were compared with non-head-

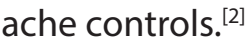

On the other hand, some studies have reported increased risk. In one study, 48713 patients with migraine were evaluated in terms of blood pressure, $\mathrm{BMI}$, serum total and high-density lipoprotein levels, and cholesterol levels. The 10-year Framingham risk score was more prominent in patients with MWO. The increase in Framingham risk score was then calculated. A lower risk when compared to patients with MWA, an increase in Framingham risk score was detected, and this increase was speculated to be the cause of low physical activity, smoking, and increase in BMI. ${ }^{[14]}$ Another study proposed that patients with migraine, especially MWA, were more commonly diagnosed with hypercholesterolemia, diabetes, and hypertension compared with controls. ${ }^{[2]}$

Cardiovascular risk factors and WMHs development have also been previously studied. A study examined 90 patients (70 MWO and $20 \mathrm{MWA}$ ) to determine the association between WMHs and cardiovascular risk factors; of these, 29 (32.2\%) had WMHs. On comparing $\mathrm{WMH}$-positive and $\mathrm{WMH}$-negative migraine patients, cardiovascular risk factors, such as smoking status, mean BMI, and serum col levels did not differ between the two groups, as we observed in our stud. [16] Similarly, another study evaluated $50 \mathrm{WMH}$-positive patients (23 MA, 15 MWA, and 12 with chronic daily headache) and $50 \mathrm{MRI}$-normal subjects and found no statistically significant difference regarding the history of hypertension, smoking, and hypercholesterolemia between the two groups. ${ }^{[10]}$

We also found that WMHs in our patients were mul- 
tiple and were located periventricularly. However, a study that evaluated 44 patients with migraine (18 MWA and $26 \mathrm{MWO}$ ) for the presence of WMHs reported that 19 of them (12 MWA and $7 \mathrm{MWO}$ ) had WMHs, which was most commonly located in the subcortical region and in deep white matter. In addition, 63\% of the patients had multiple $(\geq 9) \mathrm{WMHs}$, mostly located in the frontal lobe. ${ }^{[13]}$ Kruit et al reported that 13 of the 295 patients with migraine had WMH, and their lesions were mostly located in the pons. ${ }^{[7]}$ The typical locations of the occurrence of WMH should be considered during differential diagnosis.

When WMHs is detected, clinicians should exclude secondary causes of migraine or complicated conditions, such as CADASIL , and monitor disease progression. ${ }^{[3]}$ In a previous study, 41 patients with MWA were followed up for 33 months, and 19.5\% showed an increase in the number of WMHs lesions. Although the increase in the number of WMHs lesions has been previously reported in longitudinal studies of migraine, patients with MWA and MWO were not found to be at a risk of cognitive decline. ${ }^{[4,11]} \mathrm{A}$ recently published review paper stated that MWO may not have a direct causal relationship with lead stroke, but may share genetics, risk factors, and comorbidities with stroke. Therefore, such patients are advised for smoking cessation and oral contraceptive abstinence. In selected cases, migraine prophylaxis which is beneficial to reduce both migraine attacks and vascular risk, should be considered. ${ }^{[8]}$

There are some limitations of our study. A limited number of patients have been included in this study, and migraine headache severity could not be evaluated from the patients' data. Future studies may be planned with a large number of patients and for investigating the role of genetic factors and oxidative stress in the development of WMHs.

\section{Conclusion}

We did not find any association between cardiovascular risk factors and WMHs development in patients with MWO. Risk factors other than cardiovascular risk factors (genetic factors and oxidative stress) must be studied in future.

\section{Conflict-of-interest issues regarding the authorship or article: None declared.}

Peer-rewiew: Externally peer-reviewed.

\section{References}

1. Aradi M, Schwarcz A, Perlaki G, Orsi G, Kovács N, Trauninger A, et al. Quantitative MRI studies of chronic brain white matter hyperintensities in migraine patients. Headache 2013;53(5):752-63. [CrossRef]

2. Bigal ME, Kurth T, Santanello N, Buse D, Golden W, Robbins $M$, et al. Migraine and cardiovascular disease: a population-based study. Neurology 2010;74(8):628-35. [CrossRef]

3. Colombo B, Dalla Libera D, Comi G. Brain white matter lesions in migraine: what's the meaning? Neurol Sci 2011;32 Suppl 1:S37-40. [CrossRef]

4. Erdélyi-Bótor S, Aradi M, Kamson DO, Kovács N, Perlaki G, Orsi $G$, et al. Changes of migraine-related white matter hyperintensities after 3 years: a longitudinal MRI study. Headache 2015;55(1):55-70. [CrossRef]

5. Fazekas F, Koch M, Schmidt R, Offenbacher H, Payer F, Freidl W, et al. The prevalence of cerebral damage varies with migraine type: a MRI study. Headache 1992;32(6):287-91.

6. Headache Classification Committee of the International Headache Society (IHS). The International Classification of Headache Disorders, 3rd edition (beta version). Cephalalgia 2013;33(9):629-808.

7. Kruit MC, van Buchem MA, Launer LJ, Terwindt GM, Ferrari MD. Migraine is associated with an increased risk of deep white matter lesions, subclinical posterior circulation infarcts and brain iron accumulation: the population-based MRI CAMERA study. Cephalalgia 2010;30(2):129-36. [CrossRef]

8. Lee MJ, Lee C, Chung CS. The Migraine-Stroke Connection. J Stroke 2016;18(2):146-56. [CrossRef]

9. Porter A, Gladstone JP, Dodick DW. Migraine and white matter hyperintensities. Curr Pain Headache Rep 2005;9(4):289-93. [CrossRef]

10. Rao R, Rosati A, Liberini P, Gipponi S, Venturelli E, Sapia E, et al. Cerebrovascular risk factors and MRI abnormalities in migraine. Neurol Sci 2008;29 Suppl 1:S144-5. [CrossRef]

11. Rist PM, Kurth T. Migraine and cognitive decline: a topical review. Headache.2013;53(4):589-98. [CrossRef]

12. Rouiller N, Marques-Vidal P. Prevalence and determinants of weight misperception in an urban Swiss population. Swiss Med Wkly 2016;146:w14364. [CrossRef]

13. Seneviratne $U$, Chong W, Billimoria PH. Brain white matter hyperintensities in migraine: clinical and radiological correlates. Clin Neurol Neurosurg 2013;115(7):1040-3. [CrossRef]

14. Stovner Lj, Hagen K, Jensen R, Katsarava Z, Lipton R, Scher $A$, et al. The global burden of headache: a documentation of headache prevalence and disability worldwide. Cephalalgia 2007;27(3):193-210. [CrossRef]

15. Tana C, Tafuri E, Tana M, Martelletti P, Negro A, Affaitati G, et al. New insights into the cardiovascular risk of migraine and the role of white matter hyperintensities: is gold all that glitters? J Headache Pain 2013;14:9. [CrossRef]

16. Toghae M, Rahimian E, Abdollahi M, Shoar S, Naderan M. The Prevalence of Magnetic Resonance Imaging Hyperintensity in Migraine Patients and Its Association with Migraine Headache Characteristics and Cardiovascular Risk Factors. Oman Med J 2015;30(3):203-7. [CrossRef]

17. Winsvold BS, Hagen $K$, Aamodt AH, Stovner LJ, Holmen J, Zwart JA. Headache, migraine and cardiovascular risk factors: the HUNT study. Eur J Neurol 2011;18(3):504-11. 